\title{
PEMANFAATAN LIMBAH PLASTIK MENJADI PRODUK KERAJINAN UNTUK MENUMBUHKAN LIFESKILL SERTA KEMANDIRIAN MASYARAKAT DIFABEL
}

\section{(Utilization Of Plastic Waste Into Handicraft Products To Increased Life Skill And Independence Of Diffabel Community)}

\author{
Fahruddin Kurdi \\ Sekolah Tinggi Ilmu Kesehatan Pemkab Jombang \\ email: fahruddinkurdi@gmail.com
}

\begin{abstract}
ABSTRAK
Pelaksanaan pengabdian masyarakat ini bertujuan untuk menghasilkan Produk kerajinan yang berbahan dasar limbah menjadi produk kerajinan tangan seperti, bros, tas, tempat pensil, dan berbagai kerajinan yang kreatif. Kaum difabel dapat menyalurkan kemampuan dan bakat sehingga mereka dapat mandiri secara finansial.

Program pengapdian masyarakat ini dilaksanakan dengan tahap-tahap : Mempersiapkan alat dan metode yang digunakan dalam kegiatan; mengobservasi kegiatan jumlah dan kondisi komunitas, kemudian menyusun jadwal kegiatan; pelaksanaan proses pelatihan serta evaluasi.

Kendala yang dialami tim pelaksana adalah dalam hal berkomunikasi. Untuk mengatasi kendala tersebut komunitas suara difabel mandiri dan pelaksana akan terus berkoordinasi, dan pihak pengurus komunitas akan mencari pendamping keterampilan sehingga kalau ada masalah sewaktu-waktu dilapangan pada saat kegiatan bisa segera diatasi. Program pelatihan lifeskill untuk komunitas difabel ini perlu ada keberlanjutannya sehingga komunitas difabel ini dapat turut serta dalam segala kegiatan sehingga mereka mempunyai rasa percaya diri serta tidak termarginalkan dalam berkehidupan dan bersosial.
\end{abstract}

Keywords: difabel, lifeskill, limbah

\section{A. PENDAHULUAN}

Pada umumnya, masyarakat beranggapan bahwa kaum difabel sebagai manusia yang hanya memiliki kekurangan dan ketidakmampuan. Mindset ini harus dirubah, bahwa kaum difabel itu sebagai manusia dengan kondisi fisik yang berbeda yang mampu melakukan aktivitas dengan cara dan pencapaian yang tentunya berbeda pula. Selain itu mereka juga memiliki potensi diri dan harus didorong untuk selalu memiliki sikap positif terhadap lingkungannya.

Sebagai manusia yang beradab dan beragama, kita perlu membantu kelompok difabel ini. Bantuan tidak harus berbentuk bantuan langsung tunai, memberi sedekah atau zakat saja, tetapi dengan cara memberi ruang dan kesempatan untuk berkarya dan berusaha seperti halnya masyarakat lain dengan fisik yang sempurna..

Kendala dimasyarakat yang dialami oleh kaum difabel ini adalah tidak terbukanya akses bagi mereka untuk bisa bekerja sehingga kelompok ini menjadi rentan terhadap kemiskinan. Sudah saatnya kita sekarang membantu kaum ini dengan memberikan akses seluas-luasnya untuk mengikuti perkembangan jaman dengan berbagai tantangan yang harus mampu juga mereka pecahkan. Lifeskill perlu diberikan untuk mendukung mereka mampu mandiri di berbagai bidang utamanya dibidang ekonomi. Langkah ini sangat sesuai dengan UUD 1945 Pasal 28 (1) bahwa "setiap orang berhak mengembangkan diri melalui pemenuhan kebutuhan dasarnya, berhak mendapat pendidikan dan memperoleh manfaat dari ilmu pengetahuan dan teknologi, seni dan budaya, demi meningkatkan kualitas hidupnya dan demi kesejahteraan umat manusia".

Dalam hal ini, jenis pengembangan diri (lifeskill) yang akan diberikan adalah pelatihan tentang berbagai ketrampilan bagaimana memanfaatkan sampah rumah tangga menjadi produk yang bermanfaat yang bisa dijadikan sumber penghidupan bagi kaum difabel sehingga mereka benarbenar bisa mandiri secara finansial. 
Tantangan besar yang dihadapi adalah bagaimana mengupayakan SDM difabel pada usia produktif ini dapat ditransformasikan menjadi SDM yang memiliki kompetensi dan keterampilan melalui pendidikan dan pelatihan agar nantinya tidak menjadi beban.

Kegiatan ini akan dilaksanakan bekerjasama dengan Sekolah Luar Biasa di wilayah kabupaten Jombang. Ada 1 sekolah yang akan menjadi mitra Ibm ini, yaitu Komunitas SDM (Suara Difabel Mandiri) yang berlokasi di Kecamatan Jombang. Pemilihan mitra ini didasarkan pada observasi awal yang telah kami lakukan. Komunitas SDM Jombang merupakan komunitas penyandang disabilitas yang didirikan oleh saudara Achmad Fathul Iman dan beralamat di jln Brigjen Katamso no.20 Pulo Lor Jombang.

Berdasarkan data hasil observasi dapat digambarkan bahwa komunitas SDM telah menyediakan akses pendidikan non formal. Hal ini diupayakan supaya kaum difabel dapat memperoleh ilmu, keterampilan dan pengalaman sebagaimana orang normal pada umumnya. Namun tidak dapat dipungkiri lagi bahwa membangun aspek kognitif dan psikomotor untuk kaum difabel tidaklah semudah dan secepat yang dilakukan seperti di sekolah biasa pada umumnya.

Fakta dilapangan juga membuktikan bahwa peluang kerja yang disediakan oleh stakeholder tidaklah seluas yang disediakan untuk lulusan dari sekolah biasa. Pasalnya saat ini masih banyak perusahaan yang enggan memperkerjakan kaum difabel. Entah dengan berbagai alasan seperti efisiensi, efektifitas dan sebagainya. Karena itulah sebagaian besar pengangguran didominasi oleh kaum difabel. Berdasarkan Survei Sosial Ekonomi nasional (Susenas, 2015) diketahui bahwa dari 20 juta penyandang cacat di Indonesia, $80 \%$ atau 16 juta diantaranya adalah tidak memiliki pekerjaan. Sementara itu Hesti (2010) menyatakan bahwa kalaupun ada dinatara kaum difabel ini direkrut oleh perusahaan, namun mereka digaji lebih rendah dari pekerja lainnya. Bahkan dengan alasan keterbatasan fisik ini, kaum difabel semakin tersisihkan. Hal ini diperparah dengan Undangundang Republik Indonesia No 13
Tahun 2003 tentang ketenagakerjaan, yang keberadaannya justeru melemahkan kaum buruh dibanding pengusaha. Melihat fenomena di lapangan seperti itu, maka untuk menjadikan kaum difabel ini mampu mandiri diperlukan bekal berbagai ketrampilan (lifeskill) yang bisa dijadikan sebagai sumber kehidupan mereka kelak setelah lulus sekolah. Pembekalan ketrampilan dapat dilakukan sedini mungkin mulai dari tingkat sekolah dasar. Pembiasaan perlu dilakukan karena proses belajar untuk kaum ini memang mempunyai karakteristik khusus, yaitu butuh proses yang cukup lama, ketelatenan, kesabaran dan harus dilakukan tanpa memiliki kesan merupakan suatu beban bagi mereka. Apalagi ditambah kondisi fisik dan mental mereka yang berbeda-beda.

Diperlukan job deskripsi yang jelas didasarkan pada kemampuan mereka mengoptimalkan fisik dan mental dalam pelatihan nanti. Masing-masing kelompok akan bertanggung jawab terhadap tugas yang diberikan dan kalau memungkinkan jika sudah mahir bisa beralih ke tugas lain. Proses pelatihan ini cukup bagus untuk melatih karakter kaum difabel dalam belajar bertanggung jawab dan bekerjasama dengan orang lain. Selain itu, reward perlu diberikan bagi mereka yang telah menguasai job deskripsi tertentu dengan memberi kesempatan untuk belajar pada tugas yang lain. Jadi kondisi 2 sekolah ini sangat cocok karena dalam lokasi yang sama mempunyai jenjang sekolah berkelanjutan. Berdasarkan kondisi tersebut, perlu diberikan bekal tambahan berupa life skill untuk kaum difabel ini supaya minimal mampu bertahan hidup dan tidak bergantung pada orang disekitarnya dengan memanfaatkan barangbarang bekas yang ada disekitar kita menjadi barang yang bernilai ekonomis. Diharapkan ketrampilan ini akan berdampak positif pada kehidupan mereka karena mereka akan mendapatkan ilmu baru berupa ketrampilan, menjadi manusia yang mandiri serta tertanganinya limbah rumah tangga.

\section{B. METODE PELAKSANAAN}

Melakukan pelatihan pada komunitas difabel dalam membuat kerajinan/produk yang bernilai ekonomi. 
Luaran yang ingin dicapai dalam kegiatan ini yaitu terciptanya produk kerajinan dari limbah serta mewujudkan masyarakat difabel yang mandiri.

\section{HASIL DAN PEMBAHASAN}

Kegiatan pengabdian masyarakat ini dilaksanakan di SMP Muhamadiyah Jombang pada tanggal 3 Juni 2017 pukul 08.00 WIB yang diikuti oleh 23 peserta Komunitas Difabel Mandiri Jombang. Kegiatan diawali dengan pembukaan yang diisi oleh pelaksana dan direktur komunitas, kemudian dilanjutkan dengan kegiatan inti berupa pemaparan materi serta demonstrasi dan Evaluasi.

Sasaran kegiatan pengabdian masyarakat adalah para penyandang keterbatasan/disabilitas yang ada komunitas suara difabel jombang.

Kegiatan pengabdian terdiri dari pemaparan pengetahuan dan keterampilan yang ditujukan untuk meningkatkan lifeskill sehingga meraka dapat produktif walaupun dalam keterbatasan. kegiatan ini juga bertujuan untuk memperlihatkan bahwa penyandang disabilitas juga bisa berkarya sebagaimana orang normal.

Program kegiatan pengapdian masyarakat dilapangan telah berjalan sesuai dengan rencana yang disusun. Kendala yang muncul selama proses berasal dari kendala teknis yang meliputi jadwal kegiatan yang sering berganti serta bahan baku yang sering rusak karena siswa difabel tidak mampu mengontrol tenaga yang dimiliki pada saat proses pembuatan. Sedangkan kendala non teknis berasal dari sumber daya manusia yang terkait dalam kegiatan tersebut. Yaitu siswa difabel yang sulit untuk fokus pada satu kegiatan, kontrol diri yang sangat kurang serta faktor psikologis yang cepat berubah-ubah.

Kendala yang dialami tim pelaksana adalah dalam hal berkomunikasi. Untuk mengatasi kendala tersebut komunitas suara difabel mandiri dan pelaksana akan terus berkoordinasi, dan pihak pengurus komunitas akan mencari pendamping keterampilan sehingga kalau ada masalah sewaktu-waktu dilapangan pada saat kegiatan bisa segera diatasi. Program pelatihan lifeskill untuk komunitas difabel ini perlu ada keberlanjutannya sehingga komunitas difabel ini dapat turut serta dalam segala kegiatan sehingga mereka mempunyai rasa percaya diri serta tidak termarginalkan dalam berkehidupan dan bersosial

\section{KESIMPULAN DAN SARAN}

Peningkatkan keterampilan penyandang disabilitas sangat diperlukan guna meningkatkan lifeskill sehingga mereka sehingga dapat produktif walaupun dalam keterbatasan

Saran untuk pengabdian masyarakat ini adalah diperlukan dukungan dari pihak pemkab jombang untuk memberikan muatan lifeskill dan pengembangan yang lain sehingga penyandang disabilitas bisa berkarya sebagaimana orang normal.

\section{E. DAFTAR PUSTAKA}

Elvira Novianti Nurwarjani. 2007. Kreasi Cantik dari Bubur Kertas, Jakarta. PT. Kawan Pustika.

Putri Febriana, 2008. Membuat Aneka Suvenir, Tangerang. DeMedia Pustaka

https://www.kemsos.go $\mathrm{id} /$ modules.php?name+News\&file+articl e\&sid=1013.

http://makasar.tribunnews.com/2013/10/23/ UU No 19 Tahun 2011 